\title{
The Application of Accounting Standards in Government Accounting Accrual Basis: Health Laboratory Center for Makassar
}

\author{
Andi Asirah \\ Patria Artha University, Makassar \\ E-mail: syra.sheren@yahoo.com
}

Andi Ratna Sari

Patria Artha University, Makassar

Received: October 8, 2019 Accepted: October 30, 2019 Published: November 13, 2019

doi:10.5296/ber.v9i4.15587

URL: https://doi.org/10.5296/ber.v9i4.15587

\begin{abstract}
The purpose of this study was to analyze the constraints in the implementation of Government Accounting Standards (SAP) based on the accrual basis as well as to analyze the efforts made to overcome the existing obstacles in the implementation of Government Accounting Standards (SAP) based on the accrual basis. The Indonesian Governmental Accounting Standards Committee (KSAP) has compiled the Government Accounting Standards (SAP) accrual established by Government Regulation Number. 64 of 2013 replacing by the Government Regulation Number 71 of 2010. With the enactment of Government Regulation No. 64 of 2013, the application of accrual-based government accounting standards already have a legal basis. The enactment of Government Regulation No. 64 Year 2013 on Government Accounting Standards (SAP) based on the accrual basis brought major changes in the financial reporting system in Indonesia, which is a change from Cash Basis Accrual Basis Full towards the recognition of government financial transactions. Health laboratory center for Makassar has implemented Cash to Accrual (CTA) in 2011 until 2013.Implemented government accounting standards (SAP) based on the accrual basis in the accrual-based financial statements in 2014 is a qualified opinion (WDP) acquired by the Health laboratory center for Makassar on The Audit Board of The Republic Indonesia (BPK) audit report on the financial statements 2016 illustrate unmet reasonable levels of information presented for a particular item. From the research will be found two (2) factors; Regional Working Unit (SKPD) Health Laboratory Center for Makassar obstacles encountered in
\end{abstract}


implementing accrual-based government accounting system (SAP), human resources financial managers, and human resource asset managers who often alternated. In this study, researchers found the effort / solution by the Health Laboratory Center for Makassar on obstacles in implementing accrual-based SAP in the preparation of financial statements, namely: education and training.

Keywords: Accrual-based, Obstacle, Health laboratory, Regional working unit

\section{Background}

The state of financial reform package marked by the birth of the Act in Finance State which consists of the Indonesian law number 17 of 2003 and the Indonesian Law Number 15 of 2004. This law mandates Third importance of good financial governance based on the principles of transparency and accountability, and follow the best practices of international level (international best practices) adapted to the conditions in Indonesia. Two years after the Act 17 of 2003 was enacted, the government issued Government Regulation 24 of 2005 concerning Government Accounting Standards (SAP).

Government Accounting Standards (SAP) is a government accounting standards in the transition from the cash basis to the accrual basis, called Cash toward Accrual. But until the end of 2008, five years after the mandate of Act 17 of 2003, the government has yet to implement full accrual accounting (Kusmanadji, 2014). The government issued Government Regulation Number 71 of 2010 concerning the Government Accounting Standards, which include accrual-based (SAP) and cash basis. Accrual-based (SAP) is set and described in Annex I Regulation 71 of 2010 concerning the Government Accounting Standards. The rules in effect since October 22 of 2010 and can be immediately applied by each entity.

Finally, the interior minister regulations governing the implementation of accrual accounting have been published. on December 3 of 2013, The Ministry of Home Affairs is a ministry of the Government of Indonesia has set Regulation Number. 64 of 2013 concerning the Government Accounting Standards Implementation of Accrual Based on Local Government. Publication of regulatory interior minister is a follow up of Article 7, paragraph 3 of Government Regulation Number. 71 of 2010 on SAP. Regulation of the interior minister will be the guide for local governments in formulating accounting policies of local governments and local government accounting system (SAPD), including Standard Chart of Accounts (BAS), which is further defined in a regulation of regional head. According to Article 10, paragraph 1 of the Regulation, thr regulation of regional head of accounting policies and the SAPD must be set no later than on 31 May 2014 (Hasanuddin \& Sjahruddin, 2017). According to Government Regulation number. 71 of 2010, the adoption of accrual-based SAP in the local government should be implemented from 2015 (the fiscal year).

The Health Laboratory Center for Makassar has implemented Cash to Accrual (CTA) in 2011 until 2013. Implemented SAP in the accrual-based financial statements.in 2014 is a qualified opinion (WDP) acquired by the Health Laboratory Center for Makassar on Indonesian supreme audit (BPK) audit report on the financial statements 2016 illustrate unmet reasonable levels of information presented for a particular item (Idris et al., 2019). He had done in 
connection with the kick-off the implementation of accrual accounting in all Ministries / Institutions at March 2015 can be summarized financial statements on the basis of accrual accounting is still not optimal due to some constraints in terms of the preparation of the financial statements.

\section{Methodology}

In this study, researchers used three data collection techniques, i.e. through in-depth interviews, observation and documentation. In qualitative research, the data obtained from various sources using multiple data collection techniques. Validity and reliability of the data is determined by using the method of triangulation and triangulation of data sources. The acquired data will be conducted coding and data analysis and interpretation and conclusion. In this study, researchers used three data collection techniques.

In qualitative research, the data obtained from various sources using multiple data collection techniques. Validity and reliability of the data is determined by using the method of triangulation and triangulation of data sources. The acquired data will be conducted coding and data analysis and interpretation and conclusion. Data were analyzed through three stages of reduction, presentation and verification. Technical analysis of the data is described as follows:

1) Collecting secondary data in the form of Monthly Financial Report of Regional Working Unit (SKPD) and all accounting records and related documents.

2) Doing reduction to sort and classify data based on the purposes

3) Observations of secondary data that has been collected

4) Make a preliminary conclusion is based on secondary data that has been collected and analyzed

a. If from the previous stage is concluded that the posts related to the accrual principle has been presented in the financial statements of local government, then the next step is to find the constraints faced in the presentation of accrual-based financial statements.

b. If after the known constraints encountered in the presentation of accrual-based financial statements, the next step is to provide an understanding of the efforts that must be made by the executor / maker of the accrual-based financial statements.

5) Conducting interviews with the management of assets or represent

6) Make a final conclusion

\section{Results and Discussion}

\subsection{Analysis and Discussion}

Based on the research results obtained from interviews, observation and documentation, 
further interpretation of the findings are consistent with the theory / concept that research support. The analysis of the results of research and discussion can be described as follows:

\section{Financial Reporting in the Health Laboratory Center for Makassar}

The Health laboratory center for Makassar financial statements for fiscal 2016 have been prepared and presented in accordance with Government Regulation Number 222 / Minister of Finance Regulation (PMK). Number 05 of 2016 on Government Accounting Standards (SAP) and based on the principles of sound financial management in government. These financial statements include:

1) Budget Realization Report

The report describes the realization of the budget comparison between budget and realization, which includes elements of the Statement of Budget Realization (LRA) income and expenditure for 2016 (Fiscal Year). Revenues for 2016 (Fiscal Year) is in the form of Non-Tax Revenue amounted to 4,188,897,206 Rupiah or reached 131.34 percent of the estimated revenue of 3.189363 billion rupiah. State expenditures for the period of 2016 (fiscal year) amounted to $15,435,539,510$ rupiah or reached 88.41 percent of the budget allocation of 17.458791 billion rupiah

Table 1. The Health Laboratory Center for Makassar Budget realization 2015-2016 (Rupiah)

\begin{tabular}{|l|l|l|l|l|l|}
\hline \multirow{2}{*}{\multicolumn{1}{|c|}{ DESCRIPTION }} & \multirow{2}{*}{ PAINT } & \multicolumn{2}{c|}{$\mathbf{2 0 1 6}$} & \multirow{2}{*}{ 2015 } \\
& & \multicolumn{1}{|c|}{ BUDGET } & REALIZATION & \multirow{2}{*}{ REALIZATION } \\
\hline INCOME & & & & & \\
\hline PNBP & B.1 & 3.189363 billion & 4188897206 & 131.34 & 3841035070 \\
\hline INCOME & & 3.189363 billion & 4188897206 & 131.34 & 3841035070 \\
\hline SHOPPING & B.2 & & & & \\
\hline Operating expenditure & & & & & \\
\hline Employee expenditure & B.3 & 6.262113 billion & 6052275007 & 96.65 & 5390396183 \\
\hline shopping Goods & B.4 & 8.750757 billion & 8526922298 & 136.17 & 8066056433 \\
\hline Capital expenditure & B.5 & 2.445921 billion & 856342205 & 35.01 & 9340045273 \\
\hline Total Operating Expenditure & & 17.458791 billion & $15,435,539,510$ & 88.41 & $22,796,497,889$ \\
\hline
\end{tabular}

\section{2) Balance}

Balance of the financial position of the entity on the Assets, Liabilities, and Equity in 2016. The value of asset in 2016 (fiscal year) recorded and presented to 31,892,876,938 Rupiah consisting of: Current assets amounted to 3,268,778,771 Rupiah fixed assets (net) amounted to 28,435,328,154 Rupiah; Long-term receivables (net) amounted to USD 45.969 million. Liabilities and equity amounting to USD 279,121, 026 and 31,611,858,899 Rupiah, 
Table 2. The Health laboratory center for Makassar (Balance 31 December 2016, 2015)

\begin{tabular}{|c|c|c|c|}
\hline DESCRIPTION & NOTES & 2016 & 2015 \\
\hline \multicolumn{4}{|l|}{ ASSET / CURRENT ASSETS } \\
\hline Cash treasurer & C.1 & USD - & USD - \\
\hline Cash and cash equivalents & C. 2 & USD - & USD - \\
\hline Cash on Public Service Agency & C. 3 & $\operatorname{Rp} 2,111,213,235$ & $\operatorname{Rp} 1,896,054,105$ \\
\hline receivables BLU & C.4 & $\operatorname{Rp} 819,416,500$ & Rp 522,500,500 \\
\hline receivables and claims Short-term & C.5 & $\operatorname{Rp}(232,068,995)$ & $\operatorname{Rp} 268,381,978$ \\
\hline BLU Receivables (Net) & C.6 & $\operatorname{Rp} 587,347,505$ & Rp 254,118,522 \\
\hline inventories BLU & C.7 & Rp 561,218,031 & $\operatorname{Rp} 697,094,428$ \\
\hline Total Current Assets & & Rp 3,259,778,771 & $\operatorname{Rp} 2,847,267,055$ \\
\hline \multicolumn{4}{|l|}{ LONG-TERM RECEIVABLES } \\
\hline Bills receivable TP / SE & C. 8 & $\operatorname{Rp} 46,200,000$ & $\operatorname{Rp} 69,200,000$ \\
\hline Accounts-Receivable Long Term & C.9 & USD (231 000) & USD (346 000) \\
\hline Total Long-Term Receivables & & Rp 45,969,000 & Rp 68,854,000 \\
\hline Total assets & & Rp 45,969,000 & Rp 68,854,000 \\
\hline \multicolumn{4}{|l|}{ FIXED ASSETS } \\
\hline Soil & C. 10 & $\mathrm{Rp} 4,840,000,000$ & $\mathrm{Rp} 4,840,000,000$ \\
\hline Equipment and Machinery & C. 11 & $\operatorname{Rp} 30,481,892,858$ & Rp 30,932,804,153 \\
\hline Building and Construction & C. 12 & $\operatorname{Rp} 13,482,253,700$ & Rp 12,855,248,700 \\
\hline Roads, Irrigation, and Networks & C.13 & Rp 58,009,050 & Rp 58,009,050 \\
\hline Other Fixed Assets & C. 14 & $\mathrm{Rp} 445,898,000$ & Rp 595,802,000 \\
\hline Accumulated Depreciation of Fixed Assets & C. 15 & $\operatorname{Rp} 20,872,725,454$ & $\operatorname{Rp}(18,094,978,258)$ \\
\hline Total Fixed Assets & & $\operatorname{Rp} 28,435,328,154$ & $\operatorname{Rp} 31,186,885,645$ \\
\hline \multicolumn{4}{|l|}{ OTHER ASSETS } \\
\hline Other assets Public Service Agency & & $\mathrm{Rp} 830,152,500$ & \\
\hline Accumulated Depreciation & & $\operatorname{Rp}(680,248,500)$ & \\
\hline Total Other Assets & & Rp 149,904,000 & \\
\hline TOTAL ASSETS & & Rp 31,890,979,925 & \\
\hline \multicolumn{4}{|l|}{ LIABILITY / SHORT-TERM LIABILITIES } \\
\hline Advances from KPPN & C.16 & & \\
\hline Debt to Third Parties & C.17 & Rp 279,121,026 & $\operatorname{Rp} 205,076,310$ \\
\hline Total Liabilities & & $\operatorname{Rp} 279,121,026$ & $\operatorname{Rp} 205,076,310$ \\
\hline TOTAL LIABILITIES & & $\mathrm{Rp} 279,121,026$ & Rp 205,076,310 \\
\hline \multicolumn{4}{|l|}{ EQUITY } \\
\hline Equity & C. 18 & Rp 31,611,858,899 & $\operatorname{Rp} 33,897,930,390$ \\
\hline TOTAL EQUITY & & Rp 31,611,858,899 & Rp 33,897,930,390 \\
\hline TOTAL LIABILITIES AND EQUITY & & Rp 31,890,979,925 & $\operatorname{Rp} 34,103,006,700$ \\
\hline
\end{tabular}




\section{MlMacrothink}

Business and Economic Research ISSN 2162-4860 2019, Vol. 9, No. 4

3) Operational reports

Operational report presents a variety of The operational report-income, expenses, surplus / deficit from non-operating activities, surplus / deficit before extraordinary items, extraordinary items, and The operational report surplus / deficit, which is necessary for a fair presentation. The operational report (LO) revenue for 2016 (fiscal year) amounted to 4,462,813,207 Rupiah while total expenses amounted to $18,647,969,979$ Rupiah so that there is a deficit from operations of $(14,185,156,772)$ Rupiah. Non-operating activities and extraordinary items of each surplus of USD 586770841 so that the entity had a deficit-LO $(13,598,385,931)$ Rupiah.

Table 3. Health laboratory center for Makassar (Statements of operations 2016, 2015)

\begin{tabular}{|c|c|c|c|}
\hline OPERATING ACTIVITIES & & & \\
\hline \multicolumn{4}{|l|}{ INCOME } \\
\hline Other Non-Tax Revenue & D.1 & Rp 4,462,813,206 & Rp 4,261,821,417 \\
\hline THE AMOUNT OF INCOME & & $\operatorname{Rp} 4,462,813,206$ & $\operatorname{Rp} 4,261,821,417$ \\
\hline \multicolumn{4}{|l|}{ LOAD } \\
\hline Employee Expenses & D.2 & $\operatorname{Rp} 7,888,954,444$ & Rp 7,748,950,794 \\
\hline Expenses Inventory & D.3 & $\operatorname{Rp} 2,787,239,747$ & Rp 2,136,686,018 \\
\hline Expenses Goods and Services & D.4 & Rp 1,917,605,080 & $\operatorname{Rp} 2,185,969,938$ \\
\hline Maintenance Expenses & D.5 & Rp 1,954,526,939 & Rp 942,853,184 \\
\hline Official Travel Expenses & D.6 & $\operatorname{Rp} 827,563,049$ & Rp 547,737,010 \\
\hline Depreciation and Amortization & D.7 & Rp 3,310,405,715 & Rp 2,993,311,994 \\
\hline Allowance for Doubtful Accounts & D.8 & USD $(36,427,983)$ & Rp 266,560,270 \\
\hline Other Charges & D.9 & USD - & USD - \\
\hline TOTAL EXPENSES & & Rp 18,649,866,991 & Rp 16,822,069,208 \\
\hline SURPLUS (DEFICIT) FROM OPERATING ACTIVITIES & & $\operatorname{Rp}(14,187,053,785)$ & USD $(1,256,024,779)$ \\
\hline NON-OPERATING ACTIVITIES & D. 10 & & \\
\hline \multicolumn{4}{|l|}{ Revenue from Other Non-Operational Activity } \\
\hline SURPLUS / DEFICIT FROM NON-OPERATING ACTIVITIES & & USD - & \\
\hline Revenue Adjustment Value Stocks & & Rp 683,280,306 & $\mathrm{Rp} 78,700,000$ \\
\hline Non-Operational Expenses from Other Activities & & Rp 96,509,465 & USD - \\
\hline \multicolumn{4}{|l|}{ Inventory Value Adjustment Expenses } \\
\hline \multicolumn{4}{|l|}{ Inventory losses Damaged / Worn } \\
\hline \multicolumn{4}{|l|}{ Total Expense } \\
\hline SURPLUS / DEFICIT FROM NON-OPERATING ACTIVITIES & & Rp 586,770,841 & Rp 78,700,000 \\
\hline Operational report SURPLUS / DEFICIT & & $\operatorname{Rp}(13,600,282,944)$ & $\operatorname{Rp}(12,481,547,791)$ \\
\hline
\end{tabular}

4) Statement of Changes in Equity

Statement of changes in equity presents the increase or decrease in equity information reporting year compared with the previous year. Initial equity in fiscal year 2016 amounted to $33,897,930,390$ the operational report surplus- deficit of $(13,598,385,931)$ rupiah and then added with a correction value of non-evaluation of fixed assets (USD 147589 981) so that the equity of the 2016 (fiscal year) is $31,613,755,912$ Rupiah. 
Table 4. Health laboratory center for Makassar (Statements of changes in equity 2016, 2015)

\begin{tabular}{|c|c|c|c|}
\hline DESCRIPTION & NOTES & 31 DECEMBER 2016 & 31 DECEMBER 2015 \\
\hline INITIAL EQUITY & E.1 & Rp 33,897,930,390 & Rp 27,832,904,983 \\
\hline SURPLUS / DEFICIT LO & E. 2 & $\operatorname{Rp}(13,600,282,944)$ & $\operatorname{Rp}(12,481,547,791)$ \\
\hline \multicolumn{4}{|l|}{ CORRECTION TO ADD / REDUCE EQUITY } \\
\hline \multicolumn{4}{|l|}{ ASSET VALUE ADJUSTMENT } \\
\hline \multicolumn{4}{|l|}{ CORRECTION VALUE OF INVENTORIES } \\
\hline $\begin{array}{l}\text { CORRECTION VALUE OF FIXED } \\
\text { ASSETS NON revaluation }\end{array}$ & & $\operatorname{Rp}(147,589,981)$ & Rp $11,039,725$ \\
\hline VALUE ADJUSTMENT OF LIABILITY & E.3 & USD - & USD - \\
\hline TRANSACTIONS BETWEEN ENTITIES & E.4 & Rp 11,461,801,434 & Rp 18,535,533,473 \\
\hline ENDORSEMENT RETURNS GRANTS & E.5 & USD - & USD - \\
\hline DEPOSIT SURPLUS BLU & E.6 & USD - & USD - \\
\hline INCREASE / DECREASE IN EQUITY & & USD $(2,286,071,491)$ & Rp $18,535,533,473$ \\
\hline EQUITY & & Rp 31,611,858,899 & Rp 33,897,930,390 \\
\hline
\end{tabular}

5) Notes to the financial statements

a) The initial ceiling for the Health laboratory center for Makassar USD 20.082444 billion. Based on the letter Number KU.01 / 03 / II / 035/2016, health laboratory center for Makassar to authorize a revision to Budget Implementation Registration Form (DIPA) Number: 024.04.2.415655/2015.

b) Reconciliation of 2016 (fiscal year) carried out by the financial report reconciliation (application of e-Rekon-LK) in accordance with the letter of the Director of Information Systems and Technology Treasury number S-4529 / PB.8 / 2016 where the financial report reconciliation (application of e-Rekon-LK) is accessible via the internet

c) In presenting the Budget Realization Report for the 2016 (fiscal year) compiled and presented on the basis of cash. While the Balance Sheet, Statement of Operations and Statement of changes in equity for the 2016 (fiscal year) prepared and presented on an accrual basis.

\section{Obstacles encountered in the implementation of Accrual Based Government Accounting Standards in Health Laboratory Center for Makassar.}

He had done in connection with the kick-off the implementation of accrual accounting in all Ministries / Institutions dated 4 March 2015, there are several obstacles that become problems Regional Work Unit (SKPD) in Health Laboratory Center for Makassar in implementing SAP accrual-based financial statements. From the results of the study the researchers can be find of two (2) results Regional Work Unit (SKPD) factors, health center for health laboratory (BBLK) obstacles encountered in implementing accrual-based on Government Accounting System (SAP), financial manager and human resources are often alternated.

\section{1) Human resources (Finance Manager)}

Resources is one important factor in the implementation of policy implementation. The role of human resources and supporting applications is an important factor in implementing 
accrual-based SAP in the financial statements so that it can generate financial reports accrual basis with good quality information. Constraints related to human resources is not sufficient both in quality and quantity, both of which exist in the reporting entity that is accounting entity on the Regional Work Unit (SKPD).

\section{2) Human resources (business assets floater)}

Difficulties associated with human resources managers of the existing assets in the Regional Work Unit (SKPD) that floater that asset managers are not aware of the assets of any owned by Regional Work Unit (SKPD) these and assets anywhere that has been recorded and unrecorded area is becoming one constraints in implementing accrual-based Government Accounting System (SAP) in the financial statements.

\section{Efforts To Overcome Obstacles Faced in the Implementation of Government Accounting Standards Accrual Based on Health Laboratory Center for Makassar}

Some of the obstacles and problems as described earlier should be sought effort / solution by Health Laboratory Center for Makassar to be able to get a better opinion on the financial statements. In this study, researchers found the effort / solution by the Center for Health Laboratory Makassar on obstacles in implementing accrual-based Government Accounting System (SAP) in the financial statements.

\section{Education and training}

Center for Health Laboratory Makassar still have a problem related to human resources in implementing accrual-based Government Accounting System (SAP) in the financial statements. To overcome this problem of human resources Makassar Health Laboratory Center for working to improve the quality of human resources through training and how to conduct training and maximize the available human resources due to the limited number of existing human resources.

Efforts to improve the quality of human resources through employee training, whether conducted by health center for health laboratory (BBLK) Makassar (On the Job Training) and implemented by executing beyond BBLK include skills training, insight and laboratory religious so stick to the rules of conduct of the personnel. Improving the quality of human resources through training and education and training has been carried out by the Center for Health Laboratory Makassar but still in the introductory stage-introduction of accrual-based Government Accounting System (SAP) implementation in the preparation of financial statements. For human resource constraints asset managers who are constantly switching Health Laboratory Center for Makassar making efforts to conduct training to the managers of assets and propose to the government to always do whenever there is a change of asset manager of human resources organizing.

\section{Conclusion and Recomendation}

Based on the discussion that has been described in previous chapters, it is known that the Great Hall of Makassar Health Laboratory has implemented Cash To Accrual (CTA) in 2011 s / d 2013. Then in 2014, implemented Government Accounting System (SAP) in the 
accrual-based financial statements. Qualified opinion (WDP) acquired by the Center for Health Laboratory Makassar on BPK's audit report on the financial statements 2016 illustrate unmet reasonable levels of information presented for a particular item.

From the results of the study the researchers did researchers find of two (2) results Regional Work Unit (SKPD) factors on health center for health laboratory (BBLK) obstacles encountered in implementing accrual-based Government Accounting System (SAP) is the human resources manager of finance, human resources asset managers are often alternated, and Accrual Based Institution Accounting System (Saiba application).

Some of the obstacles and problems as described previously to be able to look for the effort / solution by the Center for Health Laboratory Makassar among others, education and training as well as release updates Accrual Based Institution Accounting System (Saiba application) version 5.3 with the addition of a menu that is used to record information on the identification reciprocal transactions between the Public Service Agency (BLU) with the Government entities Center to be presented on the reciprocal monitoring in financial report reconciliation (Applications e-Rekon \& LK).

As for suggestions that can be asked by the researcher as a result of this research is to continue to provide training and assistance to financial managers in preparing the financial statements are of good quality in the form of ongoing training, support facilities and funds, as well as improvements to some of the rules that are unsuitable.

\section{Acknowledgement}

On occasion the author would like to thank the Ministry of Research and Technology of Higher Education which has provided financial assistance and LPPM head Patria Artha University who has gave the direction and assistance during the study.

\section{References}

Grace, (2009). Application of Accrual Basis for Government Financial Reporting: Global Developments and Indonesia Journey Toward Implementation of Full Accrual Basis in 2015, Journal of Financial and Accounting Information Infoartha, 3(12), 1-12.

Harun, H., \& Kamase, H. P. (2012). Accounting change and institutional capacity: The case of a provincial government in Indonesia. Australasian Accounting, Business and Finance Journal, 6(2), 35-50.

Hasanuddin, R., \& Sjahruddin, H. (2017). The structure of emotional intelligence, spiritual intelligence and its relationship with work enthusiasm and auditor performance. Structure, 3(1). World Journal of Business and Management

Herwiyanti, E., Sukirman, S., \& Aziz, F. S. (2017). Analysis of Implementation of Accrual Based Accounting At the Inspectorate General of the Ministry of Finance. Journal of Accounting and Finance, 19(1), 13-23.

Idris, M. H., Jamali, H., \& Sjahruddin, H. (2019). Investigating the moderating role of knowledge: The relationship between auditor's experience and ethical judgment. Advances in 
Social Sciences Research Journal, 6(2), 491-503. https://doi.org/10.14738/assrj.62.6193

Kara, E., \& Kilic, Y. (2011). Accounting recording system on accrual basis at local authorities in Turkey: An application in Gaziantep local municipality. International Journal of Business and Social Science, 2(15), 244-250.

Langelo, F., Saerang, D. P. E., \& Alexander, S. W. (2015). Analysis of Application of Accrual Based Government Accounting Standards In Financial Statements On Bitung City Government. Jurnal EMBA: Jurnal Riset Ekonomi, Manajemen, Bisnis dan Akuntansi, 3(1). 1-8.

Madjid, N. C., \& Ashari, H. (2013). Institutionalization of Accrual Accounting in the Public Sector Indonesian. Journal of Accounting \& Organizational Change, 8(3), 257-285. https://doi.org/10.1108/18325911211258308

Najati, I., \& Pituringsih, E. (2016). Implementation of Accrual Based Accounting: Testing Determinants and Implications on the Quality of Financial Statement of the Ministry / Institution. Journal of Accounting University of Jember, 14(1).

Okfitasari, A. (2014). SAP Implementation of Accrual Based Accounting Presentation of Fixed Assets In Perspective Regions Opinion BPK. Journal of Accounting and Taxes, 14(02), 50-67. https://doi.org/10.29040/jap.v14i02.219

Risnaningsih, (2016). Implementation and Constraint-Based Local Government Accounting System Accrual. EKSIS, XI(2).

Satrio, M. D., Yuhertiana, I., \& Hamzah, A. (2016). Implementation of Accrual Based Government Accounting Standards in Jombang. Journal of Accounting and Finance, 18(1), 59-70.

Syarienda, Y., Basri, H., \& Fahlevi, H. (2018). Accrual Based Accounting Implementation Problems In Central Aceh Local Government. Journal of Economic Perspectives Darussalam, 4(1). https://doi.org/10.24815/jped.v4i1.10923

\section{Copyright Disclaimer}

Copyright for this article is retained by the author(s), with first publication rights granted to the journal.

This is an open-access article distributed under the terms and conditions of the Creative Commons Attribution license (http://creativecommons.org/licenses/by/4.0/). 